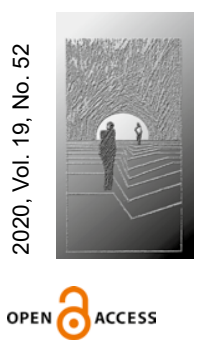

\title{
Relationships in a Family with High Academic Achievement Students
}

\begin{abstract}
RESEARCH OBJECTIVE: School achievements are an important dimension of human life and are conditioned by internal and external factors, to which family belongs. The purpose of this investigation was to answer the question how of high academic achievement students perceive their relationships in the family.
\end{abstract}

THE RESEARCH PROBLEM AND METHODS: The Family Questionnaire was used in the version "My Family, My Father and My Mother," developed by Plopa and Połomski. The subjects were 16 year-old students $(n=155)$, who achieved high scores in the lower secondary school test, and a comparative group with the average score $(n=161)$.

THE PROCESS OF ARGUMENTATION: The students assessed relationships in their families in terms of the following dimensions: communication, cohesion, identity and autonomy-control.

RESEARCH RESULTS: It was found that for students with high school performance, cohesion in relation to father is more important than for the comparative group.

CONCLUSIONS, INNOVATIONS, AND RECOMMENDATIONS: In addition, it was found that there are differences in the perception of family relationships on the basis of the gender of the studied students. Boys assessed cohesion and communication with their father on a higher level than girls. An interesting result of the study is a higher assessment of family identity in the perceptions of boys than girls.

$\rightarrow$ KEYWORDS: FAMILY, FAMILY RELATIONS, HIGH ACADEMIC ACHIEVEMENT, LOWER-SECONDARY SCHOOL TEST, COHESION, FAMILY IDENTITY

\section{Introduction}

Children's perception of family relationships is important for every aspect of their lives. How family communication, support and autonomy are shaped can have a significant impact on students' school achievements. A unique climate prevails in many families 


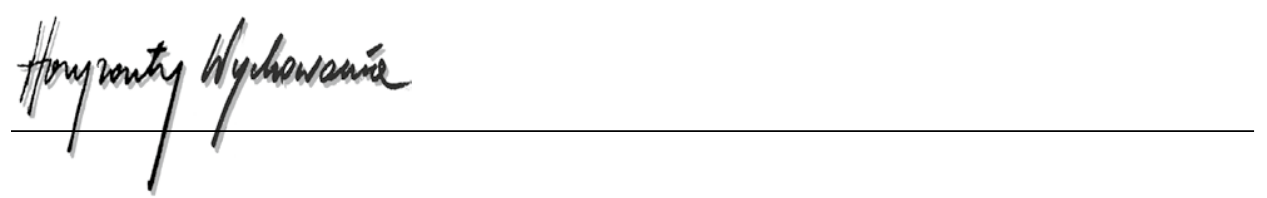

where children are gifted. It is based on giving children an enormous support, shaping democratic principles, where every family member has the right to express their opinion and, where possible, to take part in making important decisions. In addition, the child is not ignored, but is provided with a great sense of security. It is worth emphasizing that the atmosphere of emotional security is one of the predictors of a child's school achievement (Białecki \& Siemieńska, 2007; Landau \& Weissler, 1993). In following a systemic approach family relationships have a direct impact on the progress of a child's learning, and his or her achievements can differentiate the quality of relationships (Sikorski, 2011). Excessive control, pressure on the child, and lack of freedom can have a negative impact on their school performance. The student needs a great deal of freedom in order to develop their academic passions and interests. Over-controlling parents inhibit creativity of the child, who stops enjoying learning, and treats it as an unpleasant burden. The lower level of freedom, the lower will be school achievements, especially in gifted children (Sliwińska, Limont, \& Dreszer, 2008). Relationships in the family depend on such factors as the quality of communication, the degree of autonomy - control, identity and cohesion within family. It is important to focus on this in a system approach. Not only relationships with a parent, but also relationships between parents are important to the child (Plopa \& Połomski, 2010). Discussing family relationships, one should focus not only on feelings, but also on thoughts, specific activities, events and emotions. These features and their qualities will indicate a more or less close relationship. It can be concluded that among the members of the family occurs an exchange of goods, which are feelings (e.g. mutual love, respect), information and services (Plopa, 2008).

\section{Dimensions of family relationships}

\section{Dimensions of family relationships - communication}

The high quality of dialogue in the family enhances its cohesion, provides a sense of security and closeness (Braun-Gałkowska, 2009). It is also a model of positive parental communication that transcends relations between generations and peers. High quality communication in the family is characterized by honesty, openness, ability to listen and understand and empathy. With the ability to speak and listen, your immediate family is supported (Kalus, 2009). Absence or dysfunctions in communication lead to dysfunction of the family (Błasiak, 2012). An important element in the family system is also the quality of communication between the subsystems: the subsystem of spouses, and a much more complex subsystem of parents and children. The relationship between the child and the mother depends on the developmental phase, evolving from the total dependence and responsibility of the parent to the child until they reach a greater equality and partnership in family conversation. The content of family discussion and rules are changing, and this process is based on the formation of relationships and family ties (Harwas-Napierała, 2014). During adolescence, there may be difficulties in communicating between a parent 
and a teenager who strives for independence, has different views than his or her parents. However, if communication between the parent and the child is based on respect, openness and partnership, it can be positive despite the difficulties (Kozera-Mikuła, 2015). Insufficient quality of communication in the family, which is manifested in criticism and inconsistency, significantly lowers self-esteem and the children quality of life (Lorenzo-Blanco, Bares, \& Delva, 2013). In studies of gifted, parents were asked to evaluate their relationship with the child. More than $50 \%$ of the respondents considered it very good and about $30 \%$ considered it good. The authors emphasize that positive parent-child relationships are a very important element in the process of supporting the child's giftedness (Pilipczuk \& Misior, 2013).

\section{Dimensions of family relationships - cohesion}

Cohesion is a dimension of family relations that determines its equilibrium and the consequences of the parents' influence. It is expressed in close emotional relationships between family members (kindness, strong emotional bond, trust, support) (Plopa, 2011), as well as respect for the rights of every family member. Too inconsistent cohesion, characterized by inadequate problem solving, ignoring or denying family conflicts, sparse support, stiffness and emotional coldness (Plopa \& Połomski, 2010) can lead to alienation (John-Borys, 2004). A measure of cohesion is the mutual proximity of family members. It is expressed in the quality of borders, the presence of coalitions, the amount of time spent on common interests, the ability to make decisions collectively by family members. The level of cohesion changes in the course of family life. It is estimated that children see a decrease in cohesion between the ages of 13 and 17, with the greatest difference occurring at the age of 16 . Importantly, young people feel less cohesion and more autonomy, first emotionally, before they separate from the family behaviourally. In other words, teenagers feel less connected with their parents, although they still live with them and are dependent on them. They get prepared mentally for complete independence in subsequent years. During this period, the level of family cohesion differs in the assessment of adolescents from that of their parents, which often leads to conflicts. Parents, especially mothers, perceive cohesion as stronger than their teenage children (John-Borys, 2004).

\section{Dimensions of family relationships - autonomy-control}

Autonomy-control are two opposite extreme poles describing parents' approach to managing the behaviour of a child. However, the middle relation should be considered as the most favourable. A high level of autonomy and a low level of control are optimal for family functioning. This is a manifestation of parent's acceptance of the child's privacy, their independence and respect for their opinions. This kind of relationship encourages 


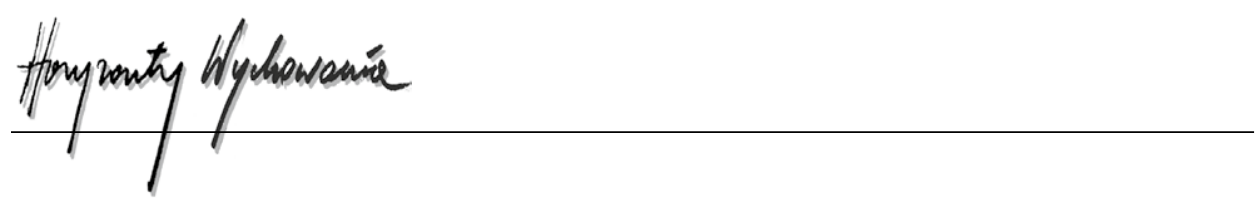

children to take their own initiatives, set up and solve problems by themselves. The parent tolerates the child's choices and respects their decisions. The opposite situation occurs when control significantly overrides autonomy. It is characterized by limitation of freedom and lack of respect for privacy (Plopa \& Połomski, 2010). The level of autonomy - the control should be appropriate to the age of the child. The older they are, the more parents have to maintain a proper balance between care and age-appropriate levels of freedom. It is important that a child could receive a level of autonomy which is adapted for their development. A too low level of independence can block the child's ability and inhibit their own confidence in their abilities. An adequate level of autonomy helps in enriching their competence and enhances self-efficacy. It also means that in addition to freedom, the child has also the feeling of parental support and when they need it, they can count on it (Gulla, 2010). Especially, adolescents need autonomy and a sense of independence in order to develop their social maturity and self-esteem (Satir, 2000).

\section{Dimensions of family relationships - identity}

Family identity is a compilation of all traditions, values and rules prevailing in a given family. A high level of this feature attests to the acceptance and identification with a family by its members. This concerns respect for and celebration of common holidays and customs. Identity is expressed in respect of moral and patriotic values that are transmitted from generation to generation. This is closely related to the boundaries in the family. Their optimal level also accounts for preservation of their identity. Too overly open boundaries can cause a decline in this feature, and consequently, can be conducive to total liberalism, loosening of principles and values. Children from such families do not derive role models from home and perceive traditions and rules as indeterminate and ambiguous (Plopa \& Połomski, 2010).

\section{Student school achievement}

Recently, there are many different criteria for student school achievement. Their preference is mainly related to the stage of learning the student. These criteria may be directly related to school - average grades, teacher and peer feedback, final and summative tests. Average grades in all subjects are always calculated at the end of each semester, and as a criterion for achievement they may be used from the fourth grade of primary school to the completion of doctoral studies. This is an objective criterion, consisting of averaged grades in all subjects (Burusic, Babarovic, \& Seric, 2012; Czerniawska \& Zawadzki, 2010).

There are various determinants of giftedness, outstanding achievements and talent. Their background is determined by individual differences, personality traits and external environment. Psychological research on the most eminently gifted children and 
adolescents mainly focuses on the predictors of school achievement (Sękowski, 2009). Identifying a gifted child causes many problems for researchers. Standard intelligence tests, such as the Wechsler Scale, can be helpful, but are not sufficient. Therefore, it is good to use tests that measure school or academic achievement (Sękowski, Siekańska, \& Klinkosz, 2009; Sękowski \& Łubianka, 2015). Furthermore, it is pointed out that outstanding abilities are not tangible, real, something that can be measured in a simple way. This is a kind of social construct (Pfeiffer, 2013).

\section{Methods}

The Family Relations Questionnaire "My Family," developed by Plopa and Połomski, is designed to study the self-assessment of the family as a whole. The method is used to research the family in the perception of adolescents between 15 and 20 years of age. It consists of 32 statements that young people assess on a 5 -point scale (1. Yes; 2 . Rather yes; 3. I do not know; 4. Rather not; 5 . No). Family relations are described by four dimensions: "Communication," "Cohesion," "Autonomy - Control," and "Identity" (Plopa \& Połomski, 2010). The Family Relations Questionnaire in the version "My Mother" and "My Father" consists of 24 items in the form of statements that the investigated subject evaluates on a five-step scale. The relationships of the investigated person with their parent can be presented in three dimensions: "Communication," "Cohesion," and "Autonomy - Control” (Plopa \& Połomski, 2010).

\section{Procedure}

The survey was implemented in schools after a prior telephone appointment. The survey time was about 20 minutes. Participants were informed about the voluntary and anonymous basis of the research. Questionnaires with missing data were rejected. Prior to the completion of the tests, the students filled out a questionnaire about their school performance, measured by the results of the lower high school exam, average of grades, and composition of the family. As a criterion for high school achievement, the percentage result of the lower secondary school test was chosen because it is the same in all schools and its purpose is to check the student's knowledge from earlier stages of education.

\section{Study group}

The survey was attended by students $(n=316)$, mainly upper secondary school students (81.5\%) aged 16 , from full families living in town (60.6\%), or in rural areas (39.4\%). Students were selected to the appropriate group on the basis of a high score in the lower-secondary school test (score higher than 90\%). The lower-secondary school test is 


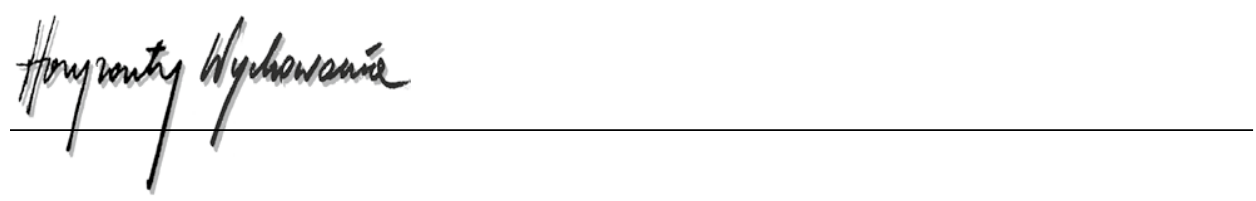

a method of checking and verifying students' knowledge at the end of this stage of education, it is the same in all schools, and its result determines to which upper secondary school students will be accepted. The second group (comparative) included students who achieved the average score of $65-45 \%$ (Table 1).

Table 1

Characteristics of students on the basis of results in the lower secondary school test

\begin{tabular}{|l|c|c|c|c|c|c|}
\hline $\begin{array}{l}\text { Result in lower } \\
\text { secondary-school test }\end{array}$ & \multicolumn{3}{|c|}{$\begin{array}{c}\text { High achievement group } \\
(\mathrm{N}=155)\end{array}$} & \multicolumn{3}{c|}{$\begin{array}{c}\text { Comparative group } \\
\text { (N =161) }\end{array}$} \\
\hline Sex & $\mathrm{N}$ & $\mathrm{M}$ & $\mathrm{SD}$ & $\mathrm{N}$ & $\mathrm{M}$ & SD \\
\hline Women & 94 & 96.49 & 3.45 & 103 & 62.41 & 11.63 \\
\hline Men & 61 & 96.38 & 3.25 & 58 & 49.22 & 7.02 \\
\hline
\end{tabular}

\section{Research questions and hypotheses}

The main aim of the study was to answer the question of how high school students perceive relationships across their families, Subsequently relationships with their father and mother, and whether the perception of the relationship is different due to the gender of the students.

The following hypotheses were formulated:

1. Students with high school achievement perceive more positively communication, cohesion, and autonomy than students in the comparative group.

2. Girls are more positive about relationships with parents than boys.

3. Students are more positive about relationships with their mother than with their father.

\section{Findings}

The high achievement group does not differ significantly from the comparative group in terms of perceiving family relationships and relationships with the mother. The differences appear in the perception of the relationship with the father. The group with high achievement in school perceives the relationship with the father as more cohesive than the comparative group. Results illustrating the perception of relationship with the father are presented in Table 2. 
Table 2

Perception of relationship with the father by students with high and low scores in the lower secondary school test - a comparative analysis

\begin{tabular}{|l|c|c|c|c|c|c|}
\hline \multirow{2}{*}{$\begin{array}{l}\text { Relations with } \\
\text { the father }\end{array}$} & \multicolumn{2}{|c|}{$\begin{array}{c}\text { High achievement group } \\
(\mathrm{N}=155)\end{array}$} & \multicolumn{2}{|c|}{$\begin{array}{c}\text { Comparative group } \\
(\mathrm{N}=161)\end{array}$} & \multirow{2}{*}{$\mathrm{t}$} & $\mathrm{p}$ \\
\cline { 2 - 5 } & $\mathrm{M}$ & $\mathrm{SD}$ & $\mathrm{M}$ & $\mathrm{SD}$ & & \\
\hline Communication & 28.45 & 7.73 & 27.04 & 8.04 & -1.58 & 0.12 \\
\hline Cohesion & 29.27 & 6.51 & 27.71 & 7.83 & -1.92 & 0.05 \\
\hline Autonomy - Control & 16.03 & 6.65 & 17.51 & 7.22 & 1.89 & 0.06 \\
\hline
\end{tabular}

Table 3

Perception of relationship with the mother by girls with high and average scores in the lower secondary school test

\begin{tabular}{|l|c|c|c|c|c|c|}
\hline \multirow{2}{*}{$\begin{array}{l}\text { Relations with the } \\
\text { mother }\end{array}$} & \multicolumn{2}{|c|}{$\begin{array}{c}\text { Girls with high achievements } \\
(\mathrm{N}=94)\end{array}$} & $\begin{array}{c}\text { Girls from comparative group } \\
(\mathrm{N}=103)\end{array}$ & \multirow{2}{*}{$\mathrm{t}$} & \multirow{2}{*}{$\mathrm{p}$} \\
\cline { 2 - 5 } & $\mathrm{M}$ & $\mathrm{SD}$ & $\mathrm{M}$ & $\mathrm{SD}$ & & \\
\hline Communication & 30.31 & 6.6 & 29.38 & 7.68 & -0.91 & 0.36 \\
\hline Cohesion & 31.72 & 6.55 & 30.12 & 7.89 & -1.55 & 0.12 \\
\hline Autonomy - Control & 17.39 & 7.15 & 19.81 & 8.28 & 2.18 & 0.03 \\
\hline
\end{tabular}

Table 4

Perception of relationship with the father by girls with high and average scores in the lower secondary school test

\begin{tabular}{|l|c|c|c|c|c|c|}
\hline \multirow{2}{*}{$\begin{array}{l}\text { Relations with } \\
\text { the father }\end{array}$} & \multicolumn{2}{|c|}{$\begin{array}{c}\text { Girls with high achievements } \\
(\mathrm{N}=94)\end{array}$} & $\begin{array}{c}\text { Girls from comparative group } \\
(\mathrm{N}=103)\end{array}$ & \multirow{2}{*}{$\mathrm{t}$} & \multirow{2}{*}{$\mathrm{p}$} \\
\cline { 2 - 5 } & $\mathrm{M}$ & $\mathrm{SD}$ & $\mathrm{M}$ & $\mathrm{SD}$ & & \\
\hline Communication & 27.11 & 7.69 & 25.6 & 8.64 & -1.29 & 0.2 \\
\hline Cohesion & 28.39 & 6.33 & 26.15 & 8.38 & -2.11 & 0.03 \\
\hline Autonomy - Control & 16.44 & 7.34 & 17.85 & 7.7 & 1.32 & 0.19 \\
\hline
\end{tabular}

Table 5

Differences in the perception of family relations by girls and boys with high scores in the lower secondary school test

\begin{tabular}{|l|l|c|c|c|c|c|}
\hline \multirow{2}{*}{ Relations in Family } & \multicolumn{2}{|c|}{$\begin{array}{c}\text { Girls } \\
(\mathrm{N}=94)\end{array}$} & \multicolumn{2}{c|}{$\begin{array}{c}\text { Boys } \\
(\mathrm{N}=61)\end{array}$} & \multirow{2}{*}{$\mathrm{t}$} & $\mathrm{p}$ \\
\cline { 2 - 5 } & \multicolumn{1}{|c|}{$\mathrm{M}$} & $\mathrm{SD}$ & $\mathrm{M}$ & $\mathrm{SD}$ & & \\
\hline Communication & 30.04 & 6.45 & 31.26 & 5.69 & -1.24 & 0.22 \\
\hline Cohesion & 30.3 & 5.96 & 31.39 & 6.03 & -1.11 & 0.27 \\
\hline Autonomy - Control & 31.95 & 5.41 & 32.38 & 5.54 & -0.48 & 0.63 \\
\hline Identity & 30.36 & 4.41 & 31.9 & 5.36 & -1.95 & 0.05 \\
\hline
\end{tabular}




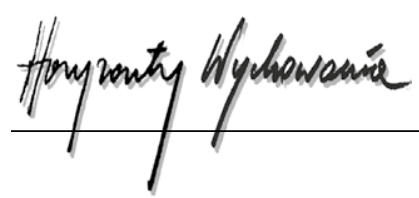

It turns out that high school students significantly differ in their perception of family relationships. Boys in this group obtained significantly higher scores in the dimension Identity in the Family Relations Questionnaire than girls (Table 5).

In view of the relationship with the mother, male and female students with high school performance do not differ significantly. On the other hand, there are differences in the perception of relationships with the father. Male students assess them more positively than female students in terms of communication quality and cohesion (Table 6).

Table 6

Differences in the perception of relationship with the father by girls and boys with high scores in the lower secondary school test

\begin{tabular}{|l|c|c|c|c|c|c|}
\hline \multirow{2}{*}{$\begin{array}{l}\text { Relations with } \\
\text { the father }\end{array}$} & \multicolumn{2}{|c|}{$\begin{array}{c}\text { Girls } \\
(\mathrm{N}=94)\end{array}$} & \multicolumn{2}{c|}{$\begin{array}{c}\text { Boys } \\
(\mathrm{N}=61)\end{array}$} & \multirow{2}{*}{$\mathrm{t}$} & $\mathrm{p}$ \\
\cline { 2 - 7 } & $\mathrm{M}$ & $\mathrm{SD}$ & $\mathrm{M}$ & $\mathrm{SD}$ & & \\
\hline Communication & 27.11 & 7.69 & 30.51 & 7.4 & -2.73 & 0.007 \\
\hline Cohesion & 28.39 & 6.33 & 30.62 & 6.61 & -2.09 & 0.03 \\
\hline Autonomy - Control & 16.44 & 7.34 & 15.41 & 5.41 & 1 & 0.32 \\
\hline
\end{tabular}

Significantly higher correlation coefficients were obtained in the high-achievement group of male students than in the group of female students for the Family Questionnaire. For both dimensions, the differences between the correlation coefficients in girls and boys are significant, for dimension Communication and Cohesion. There were no significant differences in the correlation coefficients between the high-achievement girls and the girls from the comparative group. Boys with high scores obtained a significantly higher correlation in Communication and Autonomy - Control than boys in the comparative group (Table 7 ).

Only in one case did the correlation turn out to be insignificant - in the dimension Identity in the family, and Autonomy - Control in the mother in the perception of boys. Other tendencies in both the group of girls and boys are similar. Family identity positively correlates with communication and cohesion in both the mother and the father for both gender.

Dimensions of the Family Relationship Questionnaire correlate positively in the same dimensions from the Relationship Questionnaire "My Mother and My Father," i.e. communication in family positively correlates with communication with the father and communication with the mother; the dimension Cohesion being analogous. An interesting finding is that the dimension Autonomy - Control in family is negatively correlated with the Autonomy - Control both in the mother and in the father. This trend is related to both genders, but in the group of boys the values are lower than in the group of girls. 
Table 7

Differences between correlations in perception of relationship with the mother and the father in the group with high and average scores in the lower secondary school test

\begin{tabular}{|l|c|c|c|}
\hline \multicolumn{2}{|c|}{$\begin{array}{c}\text { Correlations in perceptions of relations } \\
\text { with the mother and the father }\end{array}$} & Transformation from \\
\hline Relations & $\begin{array}{c}\text { Girls z high } \\
\text { achievements } \\
(\mathrm{N}=94)\end{array}$ & $\begin{array}{c}\text { Girls from } \\
\text { comparative group } \\
(\mathrm{N}=103)\end{array}$ & $\mathrm{p}$ \\
\hline Communication & $0.28^{* *}$ & $0.39^{*}$ & 0.196 \\
\hline Cohesion & $0.45^{*}$ & $0.44^{*}$ & 0.466 \\
\hline Autonomy - Controla & $0.42^{*}$ & $0.47^{*}$ & 0.333 \\
\hline \multicolumn{1}{|c|}{ Groups } & $\begin{array}{c}\text { Boys z high } \\
\text { achievements } \\
(\mathrm{N}=61)\end{array}$ & $\begin{array}{c}\text { Boys from } \\
\text { comparative group } \\
(\mathrm{N}=58)\end{array}$ \\
\hline Relations & $0.68^{*}$ & $0.44^{*}$ & 0.029 \\
\hline Communication & $0.67^{*}$ & $0.56^{*}$ & 0.172 \\
\hline Cohesion & $0.46^{*}$ & $0.69^{*}$ & 0.031 \\
\hline Autonomy - Control & $\begin{array}{c}\text { Girls with high } \\
\text { achievements } \\
(\mathrm{N}=94)\end{array}$ & $\begin{array}{c}\text { Boys with high } \\
\text { achievements } \\
(\mathrm{N}=61)\end{array}$ \\
\hline Groups & $0.28^{* *}$ & $0.68^{*}$ & $\mathrm{p}$ \\
\hline Relations & $0.45^{*}$ & $0.67^{*}$ & 0.001 \\
\hline Communication & $0.42^{*}$ & $0.46^{*}$ & 0,026 \\
\hline Cohesion & & & 0.355 \\
\hline Autonomy - Control & & & \\
\hline
\end{tabular}

Table 8

Correlation between dimensions of family relations and relations with the mother and the father for a group with high academic achievement according to sex

\begin{tabular}{|c|c|c|c|c|c|c|c|c|c|}
\hline & \multirow[b]{2}{*}{ Family relations } & \multicolumn{4}{|c|}{ Girls } & \multicolumn{4}{|c|}{ Boys } \\
\hline & & 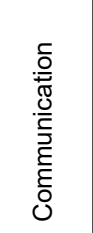 & $\begin{array}{l}\frac{.}{0} \\
0 \\
\frac{1}{0} \\
0\end{array}$ & 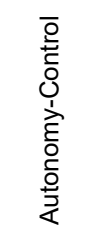 & $\begin{array}{l}\vec{i} \\
\text { 竞 } \\
\underline{\underline{D}}\end{array}$ & 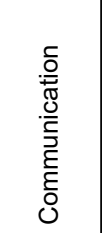 & $\begin{array}{l}\frac{c}{y} \\
0 \\
\frac{0}{0} \\
0\end{array}$ & 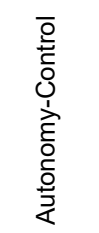 & $\begin{array}{l}\vec{i} \\
\text { 竞 } \\
\underline{\underline{D}}\end{array}$ \\
\hline \multirow{3}{*}{$\begin{array}{l}\text { Relations } \\
\text { with the } \\
\text { mother }\end{array}$} & Communication & $0.74^{*}$ & $0.73^{*}$ & $0.55^{*}$ & $0.63^{*}$ & $0.73^{*}$ & $0.66^{*}$ & $0.55^{*}$ & $0.65^{\star}$ \\
\hline & Cohesion & $0.66^{*}$ & $0.73^{*}$ & $0.47^{*}$ & $0.57^{*}$ & $0.66^{*}$ & $0.69^{*}$ & $0.52^{*}$ & $0.63^{*}$ \\
\hline & Autonomy-Control & $-0.58^{*}$ & $-0.51^{*}$ & $-0.72^{*}$ & $-0.42^{*}$ & $-0.31^{* *}$ & $-0.29^{* *}$ & $-0.45^{*}$ & -0.17 \\
\hline \multirow{3}{*}{$\begin{array}{l}\text { Relations } \\
\text { with the } \\
\text { father }\end{array}$} & Communication & $0.57^{*}$ & $0.56^{*}$ & $0.49^{*}$ & $0.54^{*}$ & $0.73^{*}$ & $0.69^{*}$ & $0.43^{*}$ & $0.59^{*}$ \\
\hline & Cohesion & $0.67^{*}$ & $0.66^{*}$ & $0.45^{\star}$ & $0.62^{*}$ & $0.76^{*}$ & $0.78^{*}$ & $0.43^{*}$ & $0.57^{*}$ \\
\hline & Autonomy-Control & $-0.49^{*}$ & $-0.37^{*}$ & $-0.57^{*}$ & $-0.27^{*}$ & $-0.38^{*}$ & $-0.37^{*}$ & $-0.34^{* *}$ & $-0.31^{* *}$ \\
\hline
\end{tabular}

* Significance at $p<0.001$ level

** Significance at $p<0.01$ level 


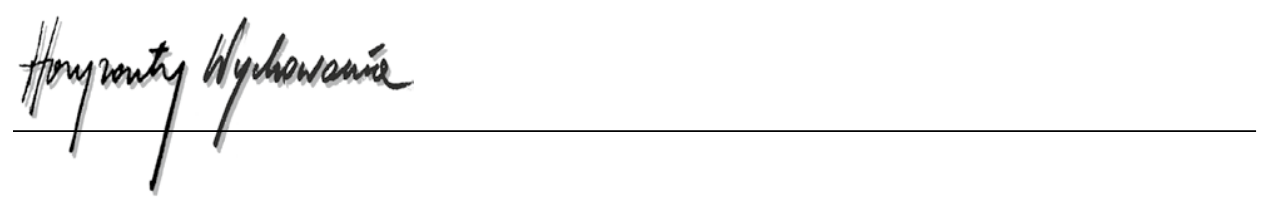

\section{Discussion of results}

The first hypothesis, which claims that students with high academic achievement are more likely to perceive positively communication, cohesion, and autonomy - control than their peers in the comparative group, found confirmation only when evaluating relationships with the father. This result is confirmed by studies of families in which gifted students with high school performance are brought up; where is a good communication quality, and a considerable freedom is afforded to children (Davidson, 2012; Moon, Jurich, \& Feldhusen, 1998; Landau, 2003). Family communication is one of the most important predictors of good family relationships influencing the development of the child and their achievement (Reichenberg \& Landau, 2009). In turn, the attitude of autonomy indicates trust in the child and acceptance of their choices. They do not have to worry about engaging in what interests them, while excessive control could block such actions (Pufal-Struzik, 2013). In our study, it was found that a group with high academic achievement assesses cohesion in father's conduct significantly higher than the comparative group. Considering the gender of the respondents, it was also found that girls with high scores in the lower secondary school test rated better father's cohesion than the ones with the average score. In addition, female students with high academic achievement ranked lower the dimension Autonomy - Control than girls in the comparative group. This is therefore the opposite of what was expected because a higher control rate indicates that girls feel overly controlled by the mother. This fact can be explained by the developmental stage of the surveyed teenagers who are often not satisfied with the level of freedom allowed by their parents.

The second hypothesis contained the assumption that girls were more positive about relationships with parents than boys. In this study, in the case of respondents with high academic achievement, results pointed to a completely opposite direction. It turns out that boys are more positive about family identity as well as communication and cohesion in relation to the father. There are no significant differences between the perception of mothers by boys and girls. According to other authors, the perception of parents by children may vary depending on the gender of the child (Plopa, 2011).

The third hypothesis assumed that students are more likely to perceive relationships with their mother than father. Adolescents similarly assess relationships with the father and the mother and thus the hypothesis was not confirmed. Studies show that adolescents on the middle level perceive similarly relationships with the mother and the father. The lowest correlation coefficient was obtained by the dimension Communication in the girls' evaluation. They evaluated communication with the mother at a higher level than communication with the father. On the other hand, boys evaluated communication with the mother and the father similarly (correlation value at 0.68 ). The difference between correlations is significant. These findings are not supported by other authors who point out that children generally better evaluate the mother than the father, and that the mother arouses stronger emotions, regardless of whether a girl or boy was investigated (Plopa, 2011). 
Cohesion with the father proved to be significant. It is manifested in very positive mutual relationships based on kindness, support and a strong emotional bond. The lack of cohesion within the family is responsible for rigid and cool relationships, indifference and isolation from the problems of other household dwellers (Plopa \& Połomski, 2010). A higher result in males in the dimension Family Identity is interesting. Family identity is an attachment to values and traditions nurtured in family. These include the celebration of holidays, customs and rules. Girls and women pay more attention to celebrations and preparations than men do. In Polish tradition, they play the most important role in shaping family identity (Dryll, 2014). In our study, it was found that it is more important for boys with high academic achievement. A full explanation of this result needs further analysis in future research.

This study has some limitations. The first is the use of only the student's perspective in the evaluation of relationships within a family. It seems that the possibility to investigate the perception of family relationships by all its members would greatly enrich the analysis with new information.

\section{BIBLIOGRAPHY}

Baniak, J. (2010). Małżeństwo i rodzina w świadomości młodzieży gimnazjalnej na tle kryzysu jej tożsamości osobowej. Kraków: NOMOS.

Białecki, I. \& Siemieńska, R. (2007). Wpływ rodziny i grup rówieśniczych na wyniki egzaminów zewnętrznych. Egzamin. Biuletyn badawczy, 12, 10-46.

Błasiak, A. (2012). Oddziaływania wychowawcze w rodzinie. Kraków: Wydawnictwo WAM.

Braun-Gałkowska, M. (2009). Poznawanie systemu rodzinnego. Lublin: Wydawnictwo KUL.

Burusic, J., Babarovic, T., \& Seric, M. (2012). Differences in elementary school achievement between girls and boys: Does the teacher gender play a role? European Journal of Psychology of Education, 27, 4, 523-538.

Czerniawska, E. \& Zawadzki, B. (2010). Aktywność strategiczna jako czynnik pośredniczący w relacji osobowość - osiągnięcia w nauce. In: A. Sękowski \& W. Klinkosz (eds.), Zdolności człowieka w ujęciu współczesnej psychologii. Lublin: Towarzystwo Naukowe KUL, 15-31.

Davidson, J.E. (2012). Is giftedness truly a gift? Gifted Education International, 28, 252-267.

Dryll, E. (2014). Narracje rodzinne. In: I. Janicka \& H. Liberska (eds.), Psychologia rodziny. Warszawa: Wydawnictwo Naukowe PWN SA, 73-95.

Gulla, B. (2010). Wielowymiarowe funkcjonowanie rodziny. Aspekty psychologiczne. In: A. Świerczek (ed.), Różne oblicza rodziny. Kraków: Wydawnictwo św. Stanisława BM, 200-231.

Harwas-Napierała, B. (2014). Specyfika komunikacji interpersonalnej w rodzinie ujmowanej jako system. In: I. Janicka \& H. Liberska (eds.), Psychologia rodziny. Warszawa: Wydawnictwo Naukowe PWN SA, 47-72.

John-Borys, M. (2004). Spójność rodziny a jej obraz w oczach dorastających dzieci. Katowice: Wydawnictwo Uniwersytetu Śląskiego.

Kalus, A. (2009). Illness in the Family Empirical Viability of Selected Theoretical Models. Polish Journal of Social Science, IV, 1, 77-99.

Kozera-Mikuła, P. (2015). Dialogue with child in adolescence. In: B. Parysiewicz, M. Wyżlic, \& K. Komsta-Tokarzewska (eds.), Dialog w rodzinie - dobre praktyki. Lublin: Wydawnictwo KUL, 61-74. 


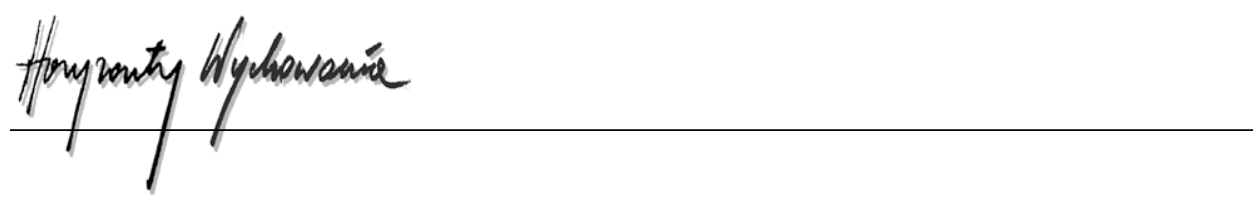

Lachowska, B. (2012). Praca i rodzina konflikt czy synergia? Konflikt i facylitacja między rolami rodzinnymi i zawodowymi - uwarunkowania i znaczenie dla jakości życia kobiet i mężczyzn. Lublin: Wydawnictwo KUL.

Landau, E. (2003). Twoje dziecko jest zdolne. Warszawa: Instytut Wydawniczy PAX.

Landau, E. \& Weissler, K. (1993). Parental Environment in Families With Gifted and Nongifted Children. The Journal of Psychology: Interdisciplinary and Applied, 127, 2, 129-142.

Lorenzo-Blanco, E., Bares, C.B., \& Delva, J. (2013). Parenting, Family Processes, Relationships, and Parental Support in multiracial and multiethnic Families: An Exploratory Study of Youth Perceptions. Family Relations, 62, 125-139.

Moon, S.M., Jurich, J.A., \& Feldhusen, J.F. (1998). Families of Gifted Children: Cradles of Development. In: R.C. Friedman \& K.B. Rogers (eds.), Talent in context: Historical and social perspectives on giftedness. Washington, DC, US: American Psychological Association, 81-99.

Pfeiffer, S.I. (2013). Serving the Gifted. Evidence-Based Clinical and Psychoeducational Practice. New York, London: Routledge Taylor \& Francis Group.

Pilipczuk, B. \& Misior, K. (2013). Rozpoznawanie i wspomaganie zdolności dzieci w wieku wczesnoszkolnym w środowisku wiejskim. In: M. Jabłonowska (ed.), Środowisko edukacyjne uczniów zdolnych. Warszawa: Wydawnictwo Universitas Rediviva, 163-174.

Plopa, M. (2008). Więzi w małżeństwie i rodzinie. Metody badań. Kraków: Impuls.

Plopa, M. (2011). Psychologia rodziny: teoria i badania. Kraków: Impuls.

Plopa, M. \& Połomski, P. (2010). Kwestionariusz Relacji Rodzinnych. Wersje dla młodzieży. WarSzawa: VIZJA PRESS \& IT.

Pufal-Struzik, I. (2013). Opieka nad dzieckiem zdolnym w rodzinie - diagnoza i wsparcie. In: M. Jabłonowska (ed.), Środowisko edukacyjne uczniów zdolnych. Warszawa: Wydawnictwo Universitas Rediviva, 59-71.

Reichenberg, A. \& Landau, E. (2009). Families of Gifted Children. In: L.V. Shavinina (ed.), International Handbook on Giftedness. Springer Science+Business Media B.V., 873-883.

Satir, V. (2000). Rodzina. Tu powstaje człowiek. Gdańsk: Gdańskie Wydawnictwo Psychologiczne.

Sękowski, A.E. (2009). Wybitne zdolności - wyjątkowość czy codzienność? Czasopismo Psychologiczne, 15, 2, 267-276.

Sękowski, A.E. \& Łubianka, B. (2015). Education of gifted students in Europe. Gifted Education International, 31, 1, 73-90.

Sękowski, A.E., Siekańska, M., \& Klinkosz, W. (2009). On Individual Differences in Giftedness. In: L. Shavinina, L.V. (eds.), International Handbook on Giftedness. Springer Verlag, 467-485.

Sikorski, W. (2011). Psychologia osiągnięć szkolnych uczniów. Czynniki konwencjonalne i niekonwencjonalne. Nysa: Oficyna Wydawnicza PWSZ.

Śliwińska, K., Limont, W., \& Dreszer, J. (2008). Perfekcjonizm a osiągnięcia szkolne uczniów zdolnych. In: W. Limont, J. Cieślikowska, J. Dreszer (eds.), Zdolności, talent, twórczość. Tom I. Toruń: Wydawnictwo Naukowe Uniwersytetu Mikołaja Kopernika, 103-118.

\section{Copyright and License}

This article is published under the terms of the Creative Commons Attribution - NoDerivs (CC BY- ND 4.0) License http://creativecommons.org/licenses/by-nd/4.0/ 